\title{
Cycling of marine dissolved organic matter. I. An experimental system
}

\author{
Ulla Li Zweifel ${ }^{1}$, Nicholas Blackburn ${ }^{1}$, Åke Hagström ${ }^{2, *}$ \\ ${ }^{1}$ Institutionen för Mikrobiologi, Umeå University, S-901 87 Umeå, Sweden \\ ${ }^{2}$ Department of Marine Ecology and Microbiology, National Environmental Research Institute Fredriksborgvej 399 , \\ PO Box 358, DK-4000 Roskilde, Denmark
}

\begin{abstract}
The degradation of dissolved organic carbon (DOC), together with bacterial growth and mortality, was studied in a multi-stage flow-through system. Particle-free sterile seawater was used as growth substrate and fed into vessels containing bacteria and viruses with or without flagellates. The residence time spanned from 30 to $1800 \mathrm{~h}$. The rate of net organic carbon consumption decreased 3 orders of magnitude with increasing residence time (from 0.45 to $0.001 \mu \mathrm{M} \mathrm{C} \mathrm{h}^{-1}$ ). Interestingly, we found a significantly higher DOC consumption in the presence of flagellates (1.3 to 10 times higher). Viruses were abundant in all culture vessels $\left(1.7\right.$ to $\left.6.5 \times 10^{10} \mathrm{I}^{-1}\right)$, indicating active virus production within the system. The number of nucleoid-containing bacteria decreased with increasing residence time from $68 \%$ of the total count at the shortest residence time to $30 \%$ at the longest residence time Also, with bacteria only, the total number of bacteria decreased at the longest residence time. We argue that with a long residence time the internal cycling of organic matter increased and that the fraction of viable bacteria decreased substantially resulting in a large fraction of 'ghosts'
\end{abstract}

KEY WORDS: DOM Degradation -Bacteria - Viability - Remineralization · Virus

\section{INTRODUCTION}

Degradation of organic matter in the microbial food web bears a resemblance to the processing of food in a digestive system. It is a mixture of physical and enzymatic processes resulting in products that can be absorbed by osmotrophic organisms. This complex transformation has been the concern of several studies aimed at explaining the distribution of organic matter in the sea (Ducklow 1983, Taylor \& Joint 1990, BarettaBekker et al. 1994). Judging from seawater culture experiments, only a small fraction of the dissolved organic matter (DOM) in seawater is biologically utilizable (Ammerman et al. 1984, Coffin et al. 1993, Middelboe \& Søndergaard 1993, Zweifel et al. 1993). The composition of the utilizable and non-degradable fractions however shows little difference; both fractions contain small and large molecules (Sundh 1992, Keil \& Kirchman 1993, Amon \& Benner 1994), and carbohy-

\footnotetext{
-Addressee for correspondence. E-mail: ake@hami1.dmu.dk
}

drates and amino acids are important components in both fractions. This paradox has been elegantly solved by the work of Keil \& Kirchman (1993), who demonstrated that amino acids and sugars added to seawater can condense to non-degradable DOM. Although this rate is fairly slow, the resulting flow of carbon can support the build-up of a dissolved organic carbon (DOC) pool with a turnover time similar to the deep ocean's mean residence time. It is therefore understandable that at any given time the majority of the reduced organic matter is found as dissolved material $<0.2 \mu \mathrm{m}$ although it originates from particles $>0.2 \mu \mathrm{m}$ (i.e. primary producers).

Azam et al. (1993) have outlined a likely scenario for organic matter degradation. Organized biological structures undergo a gradual transfer to macromolecules through physical action by predators or cell lysis caused by senescence and viruses. Following this structural 'withering', enzymatic attacks on carbohydrates, proteins, lipids and nucleic acids are initiated. The rate of cleavage depends on the complexity displayed by the substrate towards enzymatic 
attack and differs depending on the molecular environment.

Most studies conducted on bacterial degradation of DOC have been concerned with the transfer efficiency of organic matter to higher trophic levels mediated by bacteria assimilating DOC. However, since bacterial mortality is a continuous process in the food web, a constant recycling of DOC is likely. For the carbon cycle this means that cell lysis, release of DOC and subsequent uptake by bacteria will increase the bacterial production but reduce transfer of carbon to higher trophic levels due to bacteria respiring (Bratbak et al. 1992, Fuhrman 1992). This may be even more pronounced in deep waters, where lack of new production forces the organisms to recycle the existing material.

in order to establish a conccptual model of the complex system responsible for DOC degradation in the sea we designed an experimental system to study degradation during a wide range of dilution rates. We argue that steady-state values of rates and state variables to be used in modelling can be obtained by such a system that ideally replicates the increasing turnover times found in a depth gradient. In this paper we report the results of an experiment with a flow-through system harbouring mixed naturai bacteria, viruses and protozoan predators in vessels with residence times ranging over 2 orders of magnitude.

\section{MATERIALS AND METHODS}

Medium and experimental design. Water for the experiment (200 l) was collected 21 September, 1991, from $4 \mathrm{~m}$ depth at a coastal sampling station in the northern Skagerrak $\left(58^{\circ} 56^{\prime} \mathrm{N}, 11^{\circ} 45^{\prime} \mathrm{E}\right)$. The water temperature was $15^{\circ} \mathrm{C}$ and the salinity $28 \%$ on the sampling occasion. A 40 l pressure vessel was filled on deck using a diaphragm pump with an on line prefilter ( $3 \mu \mathrm{m}$ Millipore). The water was subsequently filtered through a $0.2 \mu \mathrm{m}$ filter (Millipore) at $200 \mathrm{~mm} \mathrm{Hg}$ and transferred to acid rinsed polycarbonate bottles (20 l). The glass dispensers and tubes (silicone) used in the experimental set up were fitted to the bottles and they were autoclaved twice and stored in the dark at $5^{\circ} \mathrm{C}$. Water for inoculum was sampled from the same station as the medium and kept at $10^{\circ} \mathrm{C}$ until the start of the experiment

The multi-stage flow-through system was constructed as shown in Fig. 1, including 3 stages (designated $0,1,2)$, with different mean residence time. The volume of water was 0.7 l in Stage 0, $2 \mathrm{l}$ in Stage 1 and $10 \mathrm{l}$ in Stage 2. The incoming water was fed drop-wise through a sealed glass tube to prevent back growth (Hagström et al. 1984). Ultra-pure synthetic air (AGA) was passed through a $0.2 \mu \mathrm{m}$ acrodisc (Gelman) and used to gently force the inflow to the cultures to prevent water column building in the glass tube. The pressure and gas flow were maintained to allow small bubbles to be continuously produced $\left(-1 s^{-1}\right)$. The bubbling also served as a 'stirrer' for the culture. Predatorfree inoculum was prepared by gravity filtration, 3 times through $0.6 \mu \mathrm{m}$ polycarbonate filters (MSI) using Nalgene polycarbonate filtration units. Transfer between filtration units was done through the sidearm, without removing the filters, to prevent protozoan transfer. The inoculum was added to the first vessel $\left(B_{0}\right)$. The medium flowed into the first stage $\left(B_{0}\right)$ and the outflow from $B_{0}$ was branched into 2 lines. One branch $\left(B_{1}, B_{2}\right)$ was continued with bacteria only. The second branch $\left(\mathrm{BF}_{1}, \mathrm{BF}_{2}\right)$ was inoculated with flagellates, introduced by the addition of $10 \mathrm{ml}$ of $10 \mu \mathrm{m}$ filtered water to the $\mathrm{BF}_{1}$ vessel. The bottle was then left standing for $3 \mathrm{~d}$ to allow initiation of flagellate growth before the flow was turned on. The experimental system was kept in the dark in a temperature controlled unit at $15^{\circ} \mathrm{C}$. Samples from Stages 0 and 2 could either be drawn from a sampling port or collected from an overflow of water from the vessels. In Stage 1, all outflow was transferred to Stage 2 and samples could only be taken from the sampling port. All filters and equipment used in preparing medium and inoculum were soaked in $1 \mathrm{M} \mathrm{HCl}$ and thereafter extensively rinsed in ultra-pure water (Millipore Milli-Q) before use.

Virus, bacteria, and flagellate enumeration. Samples for bacterial and flagellate enumeration were preserved with $0.2 \mu \mathrm{m}$ filtered formaldehyde $(4 \% \mathrm{v} / \mathrm{v})$. A total of 5 to $10 \mathrm{ml}$ of the samples was used for counting bacteria either by 4',6-diamidino-2-phenylindole (DAPI) or acridine orange staining and 10 to $20 \mathrm{ml}$ was used for counting flagellates by proflavin staining (Hobbie et al. 1977, Porter \& Feig 1980, Haas 1982). Cells were counted in an epifluorescence microscope

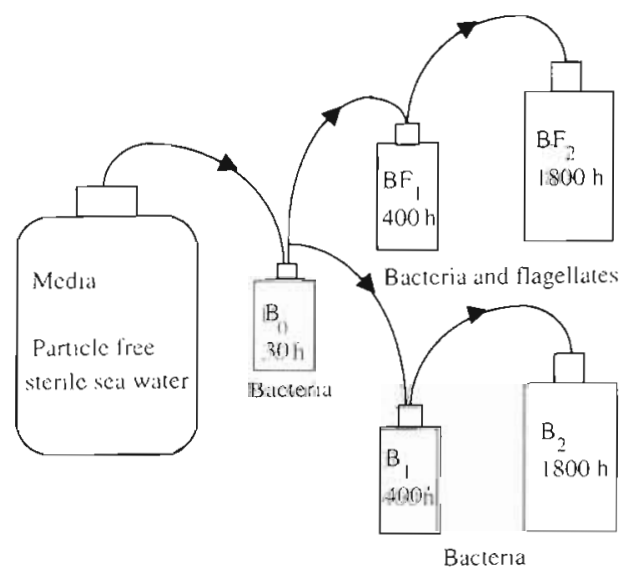

Fig. 1. Schernatic view of the experimental flow-through system. For details see 'Materials and methods' 
(Zeiss universal). At least 20 fields and 200 objects were counted for bacteria and 40 fields for flagellates. Numbers of nucleoid-containing cells (NucC) were determined essentially as described by Zweifel \& Hagström (1995). In the original protocol cells were preserved with sodium azide. From this experiment, samples preserved with formaldehyde were the only ones available. This complicated the procedure since formaldehyde itself forms surfaces that adsorb DAPI. To solve this problem the samples fixed with formaldehyde were filtered, extensively rinsed with particlefree sterile seawater $(200 \mathrm{ml})$ and then stained in the filtration funnels according to the original protocol. The accuracy of this procedure was tested by comparing NucC in samples preserved both with sodium azide and formaldehyde and treated with the respective protocol (data not shown). No significant difference was found although the original protocol is superior in reducing background staining. Bacterial strains were isolated on marine agar plates (DIFCO).

Samples for enumeration of viruses were fixed with glutaraldehyde ( $2 \% \mathrm{v} / \mathrm{v})$. The samples were centrifuged and collected on grids as described by Cochlan et al. (1993). The grids were examined in a Zeiss EM-109 transmission electron microscope (TEM) with a magnification of $\times 50000$. A minimum of 100 view fields were counted from at least 5 different grid openings.

Nutrient measurements. Inorganic as well as total nitrogen and phosphorus concentrations were determined using an autoanalyzer (Technicon TRAACS 800 ) and standard seawater methods (Grasshoff et al. 1983). Baseline and calibration solutions contained sodium chloride at concentrations close to that of the samples in order to minimize refractive index artifacts in the TRAACS flow cell. Using $50 \mathrm{~mm}$ flow cells, the detection limits, defined as twice the noise levels, were $0.3 \mathrm{Mg} \mathrm{l}^{-1}$ for or thophosphate, $0.7 \mu \mathrm{g} \mathrm{l}^{-1}$ for nitrite and nitrate, and $1.0 \mathrm{\mu g}^{-1}$ for ammonia. The procedure for the determination of total nitrogen and phosphorus included oxidation of samples with potassium peroxodisulphate in an autoclave at $120^{\circ} \mathrm{C}$ for $30 \mathrm{~min}$ (Grasshof et al. 1983). Dissolved organic nitrogen (DON) was calculated from measurements of total nitrogen in filtered samples (GF/F Whatman filters, precombusted at $600^{\circ} \mathrm{C}$ for $4 \mathrm{~h}$ ) minus the sum of inorganic nitrogen. Dissolved organic phosphorus (DOP) was calculated accordingly. Particulate organic nitrogen (PON) and particulate organic phosphorus (POP) were calculated by subtracting total $\mathrm{N}$ and $\mathrm{P}$ in filtered samples from unfiltered samples.

Dissolved organic carbon (DOC). DOC samples were filtered through $0.2 \mu \mathrm{m}$ filters (Gelman Supor) using disposable syringes (Terumo) connected to filter holders (Millipore, Swinnex 25) or by use of polycar- bonate filtration units (Nalgene). $7.5 \mathrm{ml}$ of filtered water was transferred to polypropylene test tubes (Falcon, $15 \mathrm{mll}$ and immediately acidified with $100 \mu \mathrm{l} 1.2 \mathrm{M}$ $\mathrm{HCl}$ and kept at $4^{\circ} \mathrm{C}$ until analysis. All materials in contact with the samples, including the filters and filter units, were carefully acid rinsed with $1 \mathrm{M} \mathrm{HCl}$ and washed with ultra-pure water (Millipore Milli-Q) before use. DOC was measured with a high temperature carbon analyzer (Shimadzu TOC 5000) using a 4point calibration curve with potassium biphtalate as standard. Standard solutions were run at each analysis to check for instrumental shifts. Blanks were tested before each analysis by injection of ultra-pure water (Millipore Milli-Q). The total blank (Milli-Q water + system blank) was in all cases less than $10 \mu \mathrm{M} \mathrm{C}$. Samples were not corrected for this blank. Triplicate injections showed standard deviations of 0 to $2 \%$. In most cases at least 2 individually filtered samples were analysed and showed standard deviations of 0 to $1 \%$ from the mean value of triplicate injections.

Analysis of dissolved DNA. Samples $(500 \mathrm{ml})$ were collected from each vessel and filtered through $0.2 \mu \mathrm{m}$ filters (Gelman Supor). The DNA was precipitated with 2 volumes of $99.5 \%$ ethanol. The samples were further treated according to Deflaun et al. (1986). All samples were corrected for losses by the addition of the plasmid pUC18 as an internal standard. DNA recovery was 50 to $90 \%$. The DNA was hydrolyzed and the nucleoside content was determined by high-performance liquid chromatography (HPLC) analysis as described elsewhere (Pomerantz \& McCloskey 1990).

Analysis of dissolved lipids. Samples were collected from the outflow of the vessels and filtered through $0.2 \mu \mathrm{m}$ filters (Gelman Supor). The samples were stored at $4^{\circ} \mathrm{C}$ and pooled until a sufficient amount of sample was collected. Lipids were extracted twice from 2 to $4 \mathrm{l}$ of filtered sample with $100 \mathrm{ml}$ cyclohexane (Merck, analytical grade). The cyclohexane phases were pooled and evaporated at $<40^{\circ} \mathrm{C}$. The remainder was collected and dried under $\mathrm{N}_{2}$ atmosphere, and the sample was dissolved in hexane-tetrahydrofuran (99/1 vol\%). The samples were run with HPLC analysis using column LichroCART 125-4 diol and a mobile phase with hexane, tetrahydrofuran, isopropanol and water. The detector was an evaporative light-scattering detector (ELSD, Sedex modell 45) with a Hewlett Packard 3395 integrator. Commercial lipid standards (Larodan fine chemicals AB) were used to evaluate the amount of lipids in the samples. The total lipid content was calculated by summing the amount of hydrocarbons, triglycerides and stereoles. Lipid content by weight was converted to carbon mass by multiplying by a factor of 0.8 . Phosphorus content was calculated by assuming a phospholipid content of 2 to $3 \%$ of total lipids in biological material. 
Particulate organic matter (POM). Samples (200 to $500 \mathrm{ml}$ ) were filtered through precombusted (30 min. $200^{\circ} \mathrm{C}$ ) $0.2 \mu \mathrm{m}$ silver filters (Poretics) at maximum $200 \mathrm{~mm} \mathrm{Hg}$. Blanks were prepared by filtering the particle-free medium onto precombusted filters. The total blank (filter + non-specific adhesion of $<0.2 \mu \mathrm{m}$ organic material) made up 3 to $10 \%$ of the total sample (filter + non-specific adhesion of $<0.2 \mu \mathrm{m}$ organic material + sample) and were subtracted. The filters were air dried and thereafter stored frozen prior to analysis of carbon and nitrogen with a CHN analyser (Carlo Erba).

Biovolumes and carbon biomass. Bacterial biovolumes were estimated using an automated image analyzis system (Optilab). The flagellate volumes $\left(50 \mu^{3}\right)$ weîe estinated using an ocular micrometcr. Bactcrial biovolumes were converted to carbon equivalents using a conversion factor of $180 \mathrm{fg} \mathrm{C} \mu \mathrm{m}^{3}$ (Simon \& Azam 1989). Bacterial cells lacking DNA (ghosts) were assumed to have $30 \%$ less carbon than intact cells due to loss of internal soluble pools. Flagellate biovolumes were converted to carbon equivalents using a conversion factor of $220 \mathrm{fg} \mathrm{C} \mu^{3}$ (Børsheim \& Bratbak 1987).

Bacterial production. Bacterial production was measured using the $[3 \mathrm{H}]$ thymidine incorporation method (Fuhrman \& Azam 1982). Samples (5 ml) were incubated for 1 h with $10 \mathrm{nM}[3 \mathrm{H}]$ thymidine (final concentration) under in situ conditions and processed according to the method description. Thymidine incorporation was converted to cell numbers using a range of $0.2 \times 10^{18}-2.0 \times 10^{18}$ produced cells per mole incorporated thymidine.

Limiting nutrient assay. Samples $(160 \mathrm{ml})$ were drawn from the culture vessels and filtered through $0.2 \mu \mathrm{m}$ filters (Gelman Supor). An inoculum was pre-

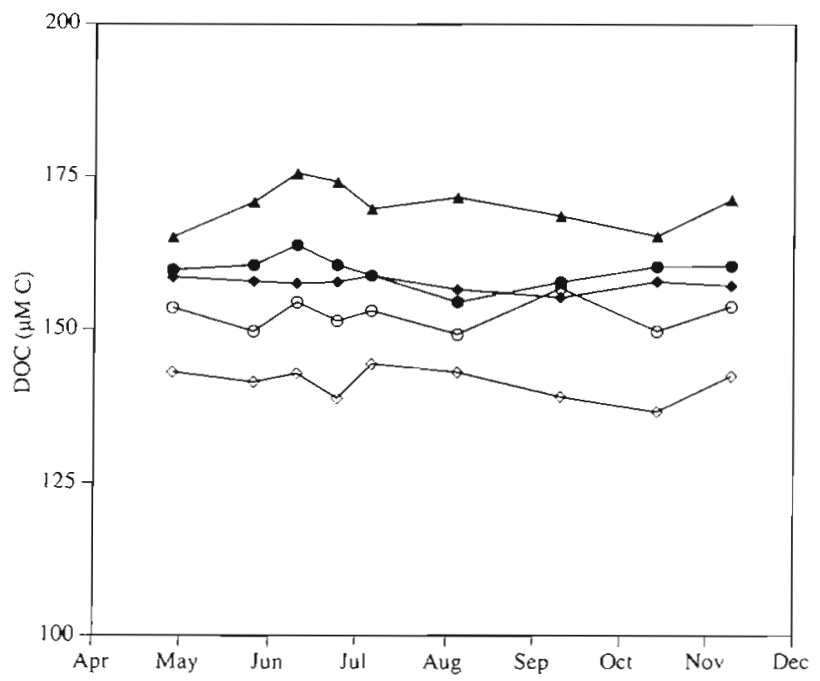

Fig 2. DOC concentrations during the experimental period (४) $\left.\mathrm{B}_{0} ;(\bullet) \mathrm{B}_{1} ; \bullet\right) \mathrm{B}_{2} ;(0) \mathrm{BF}_{1} ;(\diamond) \mathrm{BF}_{2}$ pared by mixing water from all 5 culture vessels, and the samples were subsequently filtered 3 times through $0.6 \mu \mathrm{m}$ filters (MSI) to remove predators. The inoculum was added to the filtered water to give an mitial number of $\sim 5 \times 10^{7}$ cells $l^{-1}$. The sample from each vessel was then divided into 8 subsamples and enriched with different combinations of $C, N, P$, leaving an untreated control. Nutrients were added to give an enrichment of $0.6 \mu \mathrm{MPO}_{4}-\mathrm{P}\left(\mathrm{Na}_{2} \mathrm{HPO}_{4}\right)$ and $2 \mu \mathrm{M} \mathrm{NH}_{4}$ $\mathrm{N}\left(\mathrm{NH}_{4} \mathrm{Cl}\right)$. Carbon was added as a mixed sucrose + glucose solution to give an increase in carbon of $40 \mu \mathrm{M} \mathrm{C}$. All solutions used were cross-checked for inorganic nutrient and organic carbon contamination. Yield of bacteria was counted at entry to stationary phase.

\section{RESULTS}

\section{Steady state in the flow-through system}

A flow-through system was constructed to reproduce degradation of organic matter in an experiment with increasing turnover time (Fig. 1). The experiment was run for 11 mo and samples were drawn at regular intervals. Table 1 gives a summary of the mean levels and standard deviation of biota, mineral nutrients, and organic carbon during the experimental period. Data from $B_{0}$ was collected from $1 \mathrm{wk}$ after the start of the experiment, $\mathrm{B}_{1} / \mathrm{BF}_{1}$ data were added to the database after 1 mo and $B_{2} / B_{2}$ data after 4 mo. A regression analysis of the compiled mean values failed to demonstrate significant trends with time ( $p>0.05)$ of the measured parameters in any of the 5 different culturevessels (except for nitrate in the $B_{2}$ vessel, see 'Inorganic nutrients' below). In the $\mathrm{B}_{0}$ vessel bacterial numbers reached $1.10 \times 10^{9} \mathrm{l}^{-1}$, with minor variations around the mean ( $\left.\mathrm{SD} \pm 0.14 \times 10^{9}\right)$, which is consistent with in situ numbers in surface water in the Skagerrak (Rosenberg et al. 1990). Bacterial and flagellate numbers in the other vessels also displayed the same stable conditions (Table 1). The overall stability of the system can be illustrated by the constant levels of DOC maintained during the experiment (Fig. 2).

\section{Bacteria and flagellates}

Different levels of bacterial numbers were reached in accordance with the different conditions in the vessels. The bacterial numbers were slightly higher in $B_{1}$ compared with the inflow from $B_{0}$. In $B_{2}$, with the longest residence time, bacterial counts were lower compared with the inflow from $B_{1}$, suggesting cell lysis (Table 1). Due to grazing, bacterial numbers decreased 3 -fold in the parallel vessels with flagellates (bodo- 
Table 1 Mean values of chemical and biological parameters measured during the time course of the experiment. $B_{0}$, $B_{1}$ and $\mathrm{B}_{2}$ defined in 'Medium and experimental design' Standard deviation and (n) given below values. -: no data

\begin{tabular}{|c|c|c|c|c|c|c|}
\hline Residence time (h): & Medium & $\begin{array}{l}\mathrm{B}_{0} \\
33\end{array}$ & $\begin{array}{c}B_{1} \\
369\end{array}$ & $\begin{array}{c}\mathrm{B}_{2} \\
1809\end{array}$ & $\begin{array}{l}\mathrm{BF}_{1} \\
369\end{array}$ & $\begin{array}{c}\mathrm{BF}_{2} \\
1809\end{array}$ \\
\hline \multicolumn{7}{|l|}{$\mu \mathrm{MC}$} \\
\hline $\mathrm{DOC}$ & $\begin{array}{l}185 \\
6(5)\end{array}$ & $\begin{array}{c}170 \\
4(10)\end{array}$ & $\begin{array}{c}160 \\
3(10)\end{array}$ & $\begin{array}{c}159 \\
3(10)\end{array}$ & $\begin{array}{c}155 \\
2(10)\end{array}$ & $\begin{array}{c}143 \\
3(10)\end{array}$ \\
\hline $\mathrm{POC}$ & - & $\begin{array}{l}10.8 \\
2(4)\end{array}$ & $\begin{array}{l}11.0 \\
2(2)\end{array}$ & $\begin{array}{l}10.0 \\
2(4)\end{array}$ & $\begin{array}{c}9.9 \\
2(2)\end{array}$ & $\begin{array}{c}6.9 \\
1(4)\end{array}$ \\
\hline Total C & 185 & 181 & 171 & 169 & 165 & 150 \\
\hline \multicolumn{7}{|l|}{$\mu \mathrm{M} N$} \\
\hline $\mathrm{NH}_{4}-\mathrm{N}$ & $\begin{array}{c}1.30 \\
0.11(9)\end{array}$ & $\begin{array}{c}0.39 \\
0.07(8)\end{array}$ & $\begin{array}{c}0.48 \\
0.12(7)\end{array}$ & $\begin{array}{c}0.54 \\
0.05(7)\end{array}$ & $\begin{array}{c}1.00 \\
0.38(11)\end{array}$ & $\begin{array}{c}1.02 \\
0.24(9)\end{array}$ \\
\hline $\mathrm{NO}_{3}-\mathrm{N}$ & $\begin{array}{c}0.15 \\
0.04(9)\end{array}$ & $\begin{array}{c}0.22 \\
0.05(8)\end{array}$ & $\begin{array}{c}0.14 \\
0.05(7)\end{array}$ & $\begin{array}{c}0.29 \\
0.21(7)\end{array}$ & $\begin{array}{c}0.18 \\
0.13(7)\end{array}$ & $\begin{array}{c}0.14 \\
0.06(9)\end{array}$ \\
\hline DON & $\begin{array}{c}9.10 \\
0.74(10)\end{array}$ & $\begin{array}{c}8.64 \\
0.67(4)\end{array}$ & $\begin{array}{c}8.11 \\
0.70(4)\end{array}$ & $\begin{array}{c}9.43 \\
0.17(4)\end{array}$ & $\begin{array}{c}8.40 \\
0.96(7)\end{array}$ & $\begin{array}{c}8.58 \\
1.19(5)\end{array}$ \\
\hline PON & - & $\begin{array}{c}1.21 \\
0.29(4)\end{array}$ & $\begin{array}{c}1.23 \\
0.09(4)\end{array}$ & $\begin{array}{c}0.64 \\
0.06(4)\end{array}$ & $\begin{array}{c}0.77 \\
0.22(6)\end{array}$ & $\begin{array}{c}0.56 \\
0.21(5)\end{array}$ \\
\hline Total N & 10.5 & 10.5 & 10.0 & 10.9 & 10.4 & 10.3 \\
\hline \multicolumn{7}{|l|}{ nM P } \\
\hline $\mathrm{PO}_{4}-\mathrm{P}$ & $\begin{array}{c}76 \\
17(9)\end{array}$ & $\begin{array}{c}31 \\
8(16)\end{array}$ & $\begin{array}{c}28 \\
10(17)\end{array}$ & $\begin{array}{l}22 \\
6(15)\end{array}$ & $\begin{array}{c}36 \\
10(17)\end{array}$ & $\begin{array}{l}28 \\
5\{15\}\end{array}$ \\
\hline DOP & $\begin{array}{c}117 \\
26(9)\end{array}$ & $\begin{array}{l}104 \\
8(6)\end{array}$ & $\begin{array}{c}95 \\
11(6)\end{array}$ & $\begin{array}{c}97 \\
11(4)\end{array}$ & $\begin{array}{c}119 \\
6(6)\end{array}$ & $\begin{array}{c}103 \\
13(4)\end{array}$ \\
\hline POP & - & $\begin{array}{c}56 \\
7(6)\end{array}$ & $\begin{array}{c}60 \\
6(6)\end{array}$ & $\begin{array}{c}38 \\
9(4)\end{array}$ & $\begin{array}{c}25 \\
5(6)\end{array}$ & $\begin{array}{c}16 \\
2(4)\end{array}$ \\
\hline Total P & 193 & 191 & 183 & 157 & 180 & 147 \\
\hline \multicolumn{7}{|l|}{ Biota } \\
\hline $\begin{array}{l}\text { Bacteria } \\
\left(10^{9} 1^{-1}\right)\end{array}$ & - & $\begin{array}{c}1.10 \\
0.14(24)\end{array}$ & $\begin{array}{c}1.45 \\
0.23(25)\end{array}$ & $\begin{array}{c}1.10 \\
0.11(21)\end{array}$ & $\begin{array}{c}0.58 \\
0.14(24)\end{array}$ & $\begin{array}{c}0.41 \\
0.11(21)\end{array}$ \\
\hline $\begin{array}{l}\text { Flagellates } \\
\left(10^{5} 1^{-1}\right)\end{array}$ & - & - & - & - & $\begin{array}{c}5.2 \\
1.0(15)\end{array}$ & $\begin{array}{c}3.8 \\
0.8(15)\end{array}$ \\
\hline $\begin{array}{l}\text { Bact. vol. } \\
\left(\mu \mathrm{m}^{3}\right)\end{array}$ & - & $\begin{array}{c}0.27 \\
0.008(352)\end{array}$ & $\begin{array}{c}0.25 \\
0.007(363)\end{array}$ & $\begin{array}{c}0.25 \\
0.009(232)\end{array}$ & $\begin{array}{c}0.24 \\
0.009(225)\end{array}$ & $\begin{array}{c}0.20 \\
0.009(207)\end{array}$ \\
\hline Total biomass ( $\mu \mathrm{M} \mathrm{C}$ ) & - & 4.5 & 5.1 & 3.8 & 2.0 & 1.4 \\
\hline
\end{tabular}

and ochromonas shape) although the numbers of flagellates were modest.

Bacterial biovolumes decreased significantly with increasing residence time both in the presence and absence of flagellates (Table 1). Compared with $\mathrm{B}_{0}$, the average individual volume decreased $8 \%$ in $\mathrm{B}_{1}$ and $\mathrm{B}_{2}$ with no significant difference between the latter two. In the presence of flagellates the average bacterial biovolume decreased by $13 \%$ in $\mathrm{BF}_{1}$ and $25 \%$ in $\mathrm{BF}_{2}$ compared with $\mathrm{B}_{0}$ and a significant difference was also found between $\mathrm{BF}_{1}$ and $\mathrm{BF}_{2}$. The bacterial biovolumes obtained were relatively high compared with bacterial biomass in natural waters but comparable to data from similar experimental systems (Hagström et al. 1984, Andersson et al. 1986). Judged from phenotypic expression of colony-forming bacteria, the experimental system harboured at least 14 different bacterial species that were maintained in all culture vessels (data not shown).

\section{Effect of residence time on DOC degradation}

DOC degradation was significantly higher in the $B_{0}$ vessel than in any other vessel and the net carbon degradation rate amounted to $0.45 \mu \mathrm{M} \mathrm{C} \mathrm{h}^{-1}$ (Table 2). In the consecutive vessels the degradation rates decreased 1 order of magnitude. In the last predatorfree vessel $\left(B_{2}\right)$ the DOC degradation was very low but there was also a decrease in particulate organic carbon (POC). Hence, the summed degradation of DOC and POC is also shown in Table 2. 
Table 2. Effect of decreasing dilution rate and presence of flagellates on net rates of organic carbon degradation

\begin{tabular}{|lcccc|}
\hline Dilution rate $\left(\mathrm{h}^{-1}\right)$ & \multicolumn{4}{c}{ Organic carbon degradation $\left(\mu \mathrm{M} \mathrm{C} \mathrm{h}^{-1}\right)$} \\
Bacteria only & Bacteria and flagellates \\
& DOC & DOC+POC & DOC & DOC+POC \\
\hline 0.03 & 0.45 & 0.45 & - & - \\
0.003 & 0.03 & 0.03 & 0.04 & 0.04 \\
0.0006 & 0.0006 & 0.001 & 0.006 & 0.008 \\
\hline
\end{tabular}

icant differences in the mean values between bottles except between the medium and $\mathrm{B}_{0}$, where nitrate increased significantly. In $\mathrm{B}_{2}$, however, nitrate tended to increase with time, indicating a possible nitrification process

The N:P ratio of inorganic nutrients in the medium was 19 (Table 1) indicating a surplus of nitrogen compared with a balanced bacterial growth substrate $(\mathrm{N}: \mathrm{P}=$ 10). The inorganic $N: P$ ratio increased with

Table 3. CNP composition of dissolved lipids and DNA (nucleic acids) in the experimental system. nd: not determined

\begin{tabular}{|lcccccccc|}
\hline & Medium $B_{0}$ & $B_{1}$ & $B_{2}$ & $B_{1}$ & $B_{2}$ \\
\hline Lipids & & & & & & \\
C in total lipids ( $\mu$ M C) & 1.8 & 1.7 & nd & 11 & nd & 3.9 \\
P in phospholipids (nM P) & 0.7 & 0.6 & nd & 4 & nd & 1.5 \\
C in phospholipids (nM C) & 31 & 28 & nd & 181 & nd & 67 \\
Nucleic acids & & & & & & \\
Carbon (nM C) & 12 & 6 & $0^{d}$ & 11 & 15 & 19 \\
Phosphorus (nM P) & 1.2 & 0.6 & $0^{d}$ & 1.1 & 1.5 & 1.9 \\
Nitrogen (nM N) & 2.0 & 1.0 & $0^{d}$ & 1.8 & 2.5 & 3.1 \\
Not detectable & & & & & & \\
& & & & & & \\
\hline
\end{tabular}

The degradation of DOC was significantly higher in the presence of flagellates both in $\mathrm{BF}_{1}$ and $\mathrm{BF}_{2}$ compared with $B_{1}$ and $B 2$ (Fig. 3). The total amount of degraded DOC made up $16 \%$ of the total DOC pool with bacteria only and $23 \%$ in the presence of flagellates.

Dissolved lipids were measured at one occasion at the end of the experiment in the medium, $B_{0}, B_{2}$ and $\mathrm{BF}_{2}$ vessel (Table 3 ). The concentrations of dissolved lipids were relatively similar in the medium and $B_{0}$ vessel but increased in vessel $B_{2}$ and $B_{2}$ (Table 3 ). Dissolved DNA was degraded in $B_{0}$ and $B_{1}$ while the concentration increased in the $B_{2}$ vessel. In $B F_{1}$ and $B F_{2}$ the concentration of DNA increased compared with the incoming water. residence time to 37 in $B_{2}$, indicating an increasing $P$ limitation in the system. In the presence of flagellates the ratio was even higher (42 in $\mathrm{BF}_{2}$ ), but this was due to increased ammonium concentration and not to further reduction in phosphate concentration.

The concentration of total nitrogen was constant in all 5 bottles whereas there was a significant decrease in total phosphorus concentration between $B_{1}$ and $B_{2}$

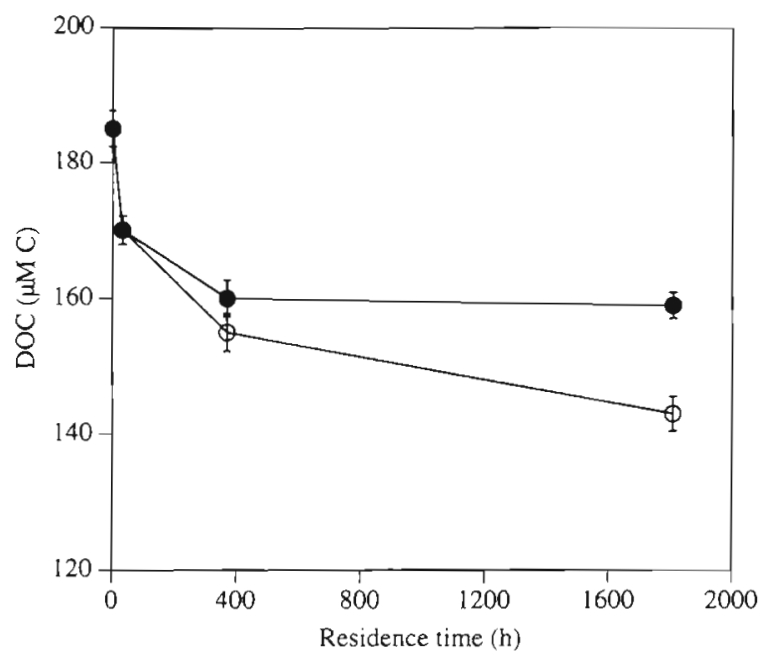

Fig. 3. Effect of increasing residence time and flagellate activity on DOC degradation. (-) Bacteria; $(0)$ bacteria and flagellates

\section{Inorganic nutrients}

The phosphate and ammonium concentration tended to decrease in the bacterial line although the only 2 consecutive vessels with significant difference were the medium and $\mathrm{B}_{0}$ (Táble 4). In $\mathrm{BF}_{1}$ and $\mathrm{BF}_{2}$ the concentrations of both phosphate and ammonium were higher than in the corresponding vessels lacking flagellates (Fig. 4). Nitrate concentrations were highly variable, and there were no signif-
Table 4. Compilation of statistics for ammonium and phosphate. Mean levels measured over the experimental period in the different vessels compared using independent $t$-test. M: medium; n: no significant difference at $95 \%$ confidence level

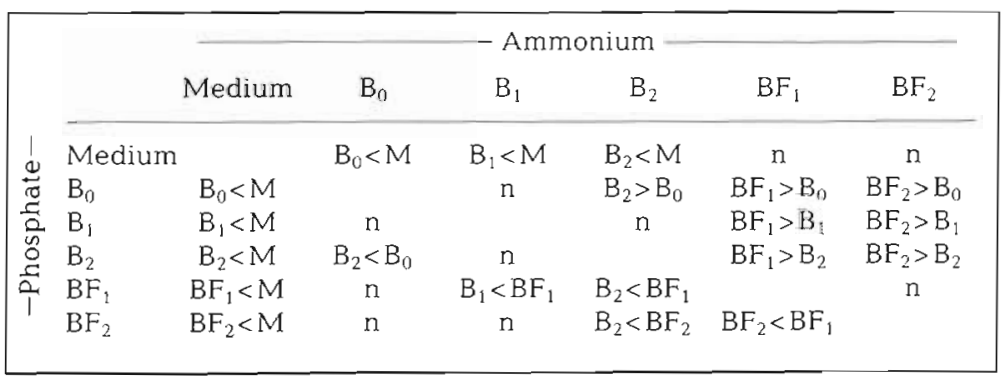




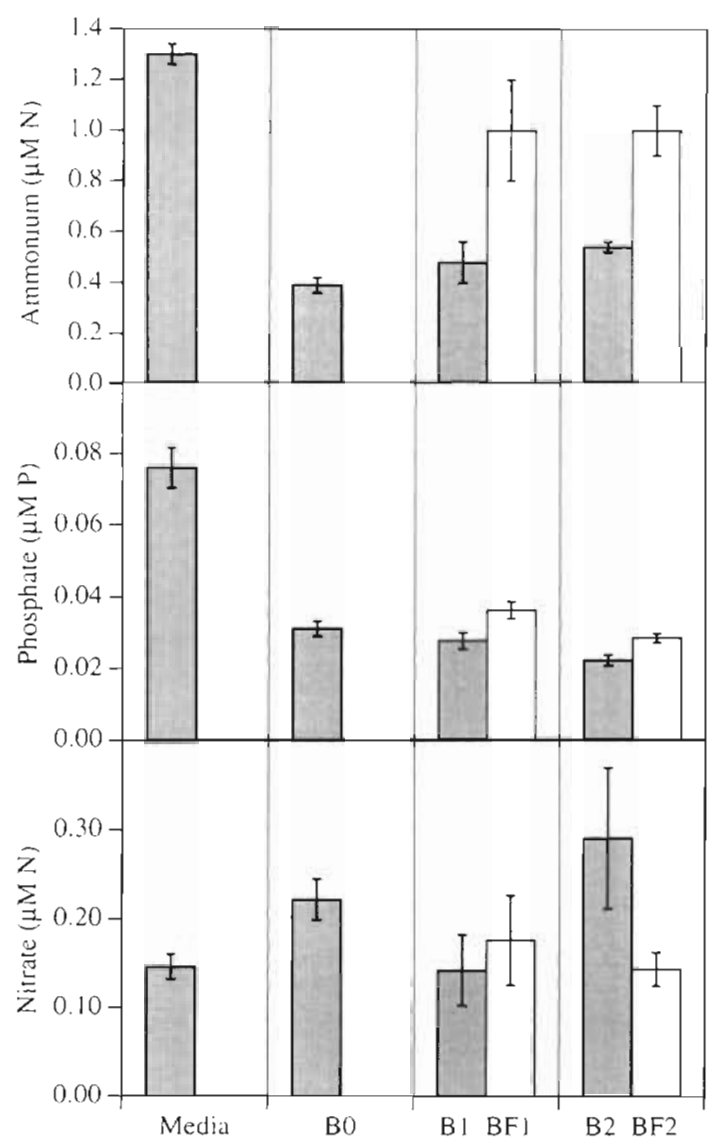

Fig. 4. Inorganic nutrients concentration in the medium and 5 culture vessels

and between $\mathrm{BF}_{1}$ and $\mathrm{BF}_{2}$. This decrease was immediate and did not proceed with time. Neither wall growth nor abiotic adhesion to the walls could explain this loss since the 'lost' phosphorus could not be found when the bottles were acid rinsed at the end of the experiment. We have currently no explanation for the loss in total phosphorus but suggest that the phosphorus with the longest residence time was modified into a structure that was not hydrolyzed to soluble reactive phosphorus by the analytical procedure.

\section{Limiting nutrient}

Direct evidence of limiting nutrient status in the bottles was determined by nutrient additions to subsamples from the 5 vessels. Yield of bacteria in water from the outflow of the culture vessels was recorded in separate experiments using additions of phosphate, ammonium and a glucose/sucrose mixture. In $\mathrm{B}_{0}$ bacterial numbers increased in the control and the addition of nutrients had minor effects on growth except when combined CNP was added (Table 5). This indi- cates that at the prevailing dilution rate $\left(0.03 \mathrm{~h}^{-1}\right)$ the medium were not exhausted and that utilizable substrate still was available in the outflow from $B_{0}$. $\ln B_{1}$ there was also a slight increase in bacterial numbers in the control and additions had little or no effect except for the combined CNP addition. In subsamples from $\mathrm{B}_{2}$ there was no detectable growth in the control bottle, showing that the substrate was completely exhausted and could not support further growth. The subcultures responded slightly to $P$ additions and considerably to combined CP and CNP. Thus, the order of limiting nutrients in the bacterial line in the flow-through system was $\mathrm{P}<\mathrm{C}<\mathrm{N}$ and nitrogen limitation was never met. The same order of limiting nutrients was found in the flagellate line and nitrogen limitation was not met there either.

\section{Bacterial viability, production and virus production}

Bacterial production measured by uptake of tritiated thymidine (TTI) decreased with increasing residence time (Table 6). In $B_{1}$ and $B_{2}$ TTI production was significantly higher than the production estimated from increase in actual bacterial numbers. The yield of bacteria in unenriched subsamples (see 'Limiting nutrient' above) supported the TTI estimate of bacterial production. The yield of bacteria in subsamples from $B_{0}$ showed that the residual substrate (outflow from $B_{0}$ ) could maintain an additional growth of $1.2 \times 10^{9}$ bacteria $\mathrm{l}^{-1}$ (Table 6 ). In $\mathrm{B}_{1}$ the residual growth was $0.3 \times 10^{9}$ bacteria $\mathrm{l}^{-1}$. This indicates that substrate equivalent to $0.9 \times 10^{9}$ bacteria $1^{-1}$ was used in $B_{1}$ and, thus, if added to the recorded increase of bacteria in the first vessel. $B_{0}$, the potential number of bacteria in $B_{1}$ would be $2.0 \times 10^{9}$ bacteria $1^{-1}$. Compared to the actual counts of bacteria in $B_{1}\left(1.5 \times 10^{9}\right.$ bacteria $\left.\mathrm{l}^{-1}\right)$, it follows that $0.5 \times 10^{9}$ bacteria $1^{-1}$ must have disintegrated. In $B_{2}$ the substrate was completely exhausted of nutrients and no further growth was possible on $0.2 \mu \mathrm{m}$ filtered sub-

Table 5. Limiting nutrient experiment on subsamples from the 5 vessels. Numbers are given in percent growth compared with numbers of bacteria in the original vessels calculated as: (Yield in subsample/Bacterial numbers in flow-through vessel) $\times 100$. Zero percent indicates no further growth

\begin{tabular}{|lrrrrrrrr|}
\hline Bottle & Control & $C$ & $N$ & $C N$ & $P$ & $N P$ & $C P$ & $C N P$ \\
\hline $\mathrm{B}_{0}$ & 110 & 100 & 105 & 90 & 130 & 140 & 170 & 460 \\
$\mathrm{~B}_{1}$ & 20 & 10 & 20 & 30 & 30 & 20 & 30 & 60 \\
$\mathrm{~B}_{2}$ & 0 & 0 & 0 & 0 & 5 & 5 & 50 & 90 \\
$\mathrm{BF}_{1}$ & 50 & 40 & 40 & 40 & 90 & 100 & 200 & 440 \\
$\mathrm{BF}_{2}$ & 40 & 40 & 40 & 40 & 50 & 50 & 80 & 115 \\
& & & & & & & & \\
\hline
\end{tabular}


Table 6. Bacterial production according to actual and potential increase in bacterial numbers compared to bacterial production measured as uptake of tritiated thymidine. nd: not determined not possible to quantify due to flagellate predation

\begin{tabular}{|c|c|c|c|c|c|c|}
\hline & & $\mathrm{B}_{0}$ & $\mathrm{~B}_{1}$ & $\mathrm{~B}_{2}$ & $\mathrm{BF}_{1}$ & $\mathrm{BF}_{2}$ \\
\hline & & $A$ & $B$ & $C$ & $D$ & $E$ \\
\hline Yield of bactena in subsamples $\left(\times 10^{9} \mathrm{l}^{-1}\right)$ & 1 & 1.2 & 0.3 & 0 & 0.3 & 0.2 \\
\hline Actual number of bacteria $\left(\times 10^{9} \mathrm{l}^{-1}\right)$ & 2 & 1.1 & 1.5 & 1.1 & 0.6 & 0.4 \\
\hline Potential number of bacteria $\left(\times 10^{9} \mathrm{I}^{-1}\right)$ & 3 & $1.1^{\mathrm{a}}$ & $\stackrel{2.0}{[A 3+(A 1-B 1)]}$ & $\frac{2.3}{[B 3+(B 1-C 1)]}$ & nd & nd \\
\hline Disintegrated bacteria $\left(\times 10^{9} \mathrm{l}^{-1}\right)$ & 4 & - & $\begin{array}{c}0.5 \\
(B 3-B 2)\end{array}$ & $\begin{array}{c}0.7 \\
(B 2-C 2+B 1)\end{array}$ & nd & nd \\
\hline Bact. prod based on actual number ( $\times 10^{6}$ cells h $\left.\mathrm{h}^{-1} \mathrm{l}^{-1}\right)$ & & 33 & 0.9 & 0 & nd & nd \\
\hline Bact. prod. based on potential number $\left(\times 10^{6}\right.$ cells $\left.\mathrm{h}^{-1} \mathrm{I}^{-1}\right)$ & & 33 & 5.1 & 1.3 & nd & nd \\
\hline Bact. prod. based on $\operatorname{TTI}^{6}\left(\times 10^{6}\right.$ cells h$\left.{ }^{-1} \mathrm{I}^{-1}\right)$ & & $8-80$ & $4-40$ & $0.8-8$ & $1-10$ & $0.7-7$ \\
\hline
\end{tabular}

samples. Thus, substrate equivalent to $0.3 \times 10^{9}$ bacteria $\mathrm{l}^{-1}$ (residual from $\mathrm{B}_{1}$ ) was used in $\mathrm{B}_{2}$ for bacterial growth. Compared with the incoming water from $B_{1}$, the number of bacteria in $B_{2}$ decreased by $0.4 \times 10^{9}$ bacteria $\mathrm{I}^{-1}$. Thus, in $\mathrm{B}_{2} 0.7 \times 10^{9}$ bacteria $\mathrm{l}^{-1}$ were disintegrated per each residence time. As seen in Table 6 , the production rates estimated from TTI were in between the range of production estimated from the yield data. We therefore concluded that bacterial growth did occur at long residence times as well, although little or no increase in total bacterial count could be detected.

The potential viability of the bacterial community was assessed by counting the number of NucC. This number represents a maximum number of actively growing bacteria since moribund phage-infected bacteria are included. The fraction of NucC was at most $68 \%$ of total count in $\mathrm{B}_{0}$ and decreased to $20 \%$ with increasing residence time (Table 7. Fig. 5). Accordingly, a high number of bacterial ghosts were included in the total counts of bacteria. The number of NucC decreased more rapidly in the presence of flagellates, possibly due to selective grazing on live bacteria.

A substantial number of viruses was found in all stages of the flow-through system (Table 7). The number of viruses increased with increasing residence in the bacterial line. In the presence of flagellates the number of viruses increased in $\mathrm{BF}_{1}$ compared with the inflow but decreased in $\mathrm{BF}_{2}$. In $B_{0}$ the number of viruses and ghosts was $1.7 \times 10^{10} \mathrm{I}^{-1}$ and $3.5 \times 10^{8}$ $1^{-1}$ respectively, resulting in an appar-

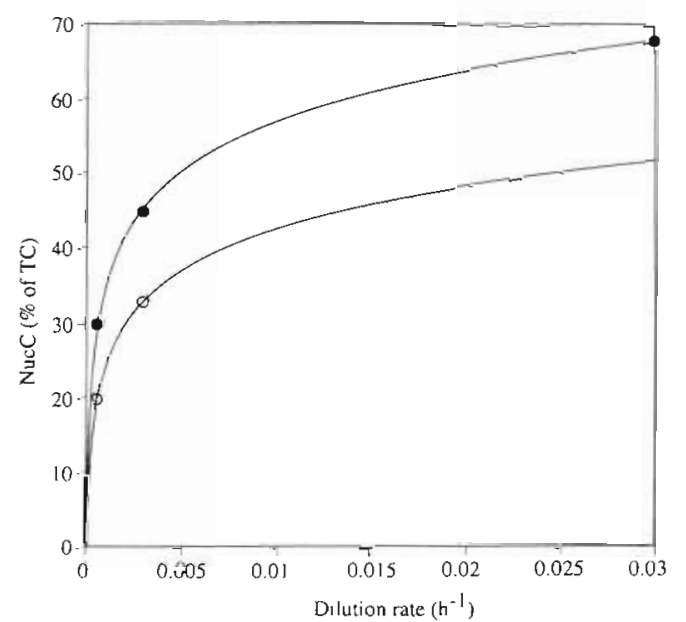

Fig. 5. Nucleoid-containing bacteria (NucC) versus dilution rate. TC: total count of bacteria. Line represents exponential curve fits. ( Bacteria $(0)$ bacteria and flagellates

Table 7 Effect of changing dilution rate and flagellate grazing on abundance of virus, nucleoid-containing bacteria (NucC) and ghosts. IC: total count of bacteria. Standard deviation and ( $\mathrm{n}$ ) given below values

\begin{tabular}{|c|c|c|c|c|c|c|}
\hline Vessel & $\begin{array}{l}\text { Dilution rate } \\
\qquad\left(h^{-1}\right)\end{array}$ & $\begin{array}{l}\text { Bacteria } \\
\left(10^{9} 1^{-1}\right)\end{array}$ & $\begin{array}{c}\text { Virus } \\
\left(10^{10} \mathrm{l}^{-1}\right)\end{array}$ & $\begin{array}{c}\text { NucC } \\
\left(10^{9} \mathrm{~L}^{-1}\right)\end{array}$ & $\begin{array}{l}\text { Ghosts } \\
\left(10^{9} \mathrm{l}^{-1}\right)\end{array}$ & $\begin{array}{c}\text { Fraction NucC } \\
(\% \text { of } \mathrm{TC})\end{array}$ \\
\hline $\begin{array}{l}\text { Bacteria } \\
\text { only }\left(\mathrm{B}_{0}\right)\end{array}$ & 0.03 & $\begin{array}{c}1.10 \\
0.14(24)\end{array}$ & $\begin{array}{c}1.7 \\
0.6(2)\end{array}$ & $\begin{array}{c}0.75 \\
0.05(2)\end{array}$ & 0.35 & 68 \\
\hline $\begin{array}{l}\text { Bacteria } \\
\text { only }\left(B_{1}\right)\end{array}$ & 0.003 & $\begin{array}{c}1.45 \\
0.23(25)\end{array}$ & $\begin{array}{c}2.1 \\
0.01(2)\end{array}$ & $\begin{array}{c}0.65 \\
0.06(2)\end{array}$ & 0.80 & 45 \\
\hline $\begin{array}{l}\text { Bacteria } \\
\text { only }\left(B_{2}\right)\end{array}$ & 0.0006 & $\begin{array}{c}1.10 \\
0.11(21)\end{array}$ & $\begin{array}{c}6.5 \\
1.3(2)\end{array}$ & $\begin{array}{c}0.33 \\
0.04(2)\end{array}$ & 0.77 & 30 \\
\hline $\begin{array}{l}\text { Bacteria } \\
+ \text { flag. }\left(\mathrm{BF}_{1}\right)\end{array}$ & 0.003 & $\begin{array}{c}0.52 \\
0.14(24)\end{array}$ & $\begin{array}{c}4.8 \\
0.2(2)\end{array}$ & $\begin{array}{c}0.17 \\
0.03(2)\end{array}$ & 0.25 & 33 \\
\hline $\begin{array}{l}\text { Bacteria } \\
+ \text { flag. }\left(\mathrm{BF}_{2}\right)\end{array}$ & 0.0006 & $\begin{array}{c}0.41 \\
0.11(21)\end{array}$ & $\begin{array}{l}3.8 \\
0.9(2)\end{array}$ & $\begin{array}{c}0.08 \\
0.02(2)\end{array}$ & 0.33 & 20 \\
\hline
\end{tabular}


ent burst size of 50 viruses per lysed cell. This is a crude estimate since part of the lysed cells may not be microscopically identifiable as ghosts and part of the ghosts may have been generated through autolysis.

\section{Particulate organic matter}

Total POC (retention on $0.2 \mu \mathrm{m}$ Ag-filter) was high throughout the system and could not be solely attributed to bacterial and flagellate carbon. Using the estimate of carbon biomass (Table 1), the contribution of bacterial and flagellate carbon to the total particulate carbon pool was only $42 \%$ in $\mathrm{B}_{0} .50 \%$ in $\mathrm{B}_{1}, 46 \%$ in $\mathrm{B}_{2}$ $21 \%$ in $\mathrm{BF}_{1}$ and $18 \%$ in $\mathrm{BF}_{2}$. Unspecific binding of initially present DOC did not 'contaminate' the filters since filtered medium water was used as a blank for the POC measurements. The nitrogen and phosphorus contents in the biota were calculated from the PON and POP estimates derived from nutrient analysis (Table 1). C:P ratios were -80 to 85 and relatively constant in all culture vessels. The $\mathrm{C}: \mathrm{N}$ ratios were 4 in $\mathrm{B}_{0}$ and $B_{1}$ and increased to 6 in vessel $B_{2}$. In the vessels including flagellates the $\mathrm{C}: \mathrm{N}$ ratio of the biota was $\sim 2$. This value appears to be low for the organisms present but indicates a trend of increasing nitrogen availability in the presence of flagellates. The $\mathrm{C}: \mathrm{N}$ ratio of filterable POM in all vessels was 10 to 15 , indicating a surplus of carbon compared with the biota. Thus, carbonrich material with characteristics allowing retention on $0.2 \mu \mathrm{m}$ filters must have been produced within the system. A figure of POC distribution, showing the contribution of NucC and ghosts, was compiled (Fig. 6). We have assumed that ghosts have $30 \%$ less carbon than intact bacteria due to loss of internal soluble pools. Detrital carbon ('invisible POC') made up the largest pool of POC in all culture vessels.

\section{Utilizable pools of essential nutrients}

The consumption of inorganic versus organic nitrogen and phosphorus was calculated in $\mathrm{B}_{0}$. An increase of $0.056 \mu \mathrm{M}$ P-POP was matched by a decrease of $0.012 \mu \mathrm{M}$ P-DOP and $0.045 \mu \mathrm{M}$ P-DIP (dissolved inorganic phosporus). Thus, $21 \%$ of the bacterial Pdemand was met from the DOP pool while $80 \%$ was obtained from the DIP pool. The corresponding figures for nitrogen utilization were an increase in $1.23 \mu \mathrm{M} \mathrm{N}$ PON and a decrease of $0.36 \mu \mathrm{M} \mathrm{N}$-DON and $0.89 \mu \mathrm{M}$ $\mathrm{N}$-DIN corresponding to a $30 \%$ contribution from the DON pool and $72 \%$ from the DIN pool.

In addition, the total pool of utilizable substrate was estimated using the yield of bacteria in the limiting nutrient experiments. Utilizable phosphorus was $0.11 \mu \mathrm{M}$

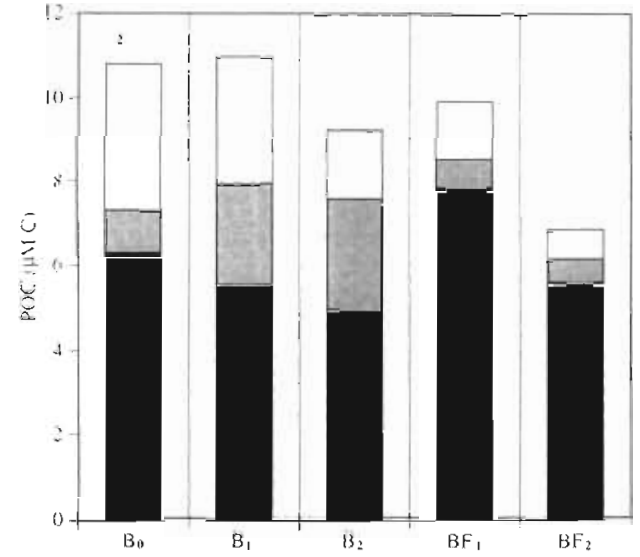

Fig. 6. POC distribution in the 5 cultures vessels. Dark colour represents dead organic material not visible in the microscope. Grey colour represents dead bacteria still visible in the microscope. Light colour represents live bacteria

P, calculated from the yield of bacteria in the $\mathrm{CN}$ enriched cultures using the bacterial P-content obtained in this study. Accordingly, the pool of utilizable nitrogen was $2.33 \mu \mathrm{M} \mathrm{N}$, calculated from the yield in CP-enriched cultures. The utilizable pool of carbon was $20 \mu \mathrm{M} \mathrm{C}$ in the bacterial line and $35 \mu \mathrm{M} \mathrm{C}$ in the flagellate line (difference between the medium and Stage 2). These values imply pools of utilizable substrates with $C: N: P$ ratios of $180: 22: 1$ in the bacterial line and $320: 22: 1$ in the flagellate line

\section{DISCUSSION}

In the experimental system, the inflow from the medium may be considered as an autotrophic compartment renewing the organic substrate in $\mathrm{B}_{0}$ approximately every day. The steady-state values in the $B_{0}$ vessel indicated that the system mimicked the turnover of organic matter and the bacterial community at rates similar to those found in surface waters (Sieburth et al. 1977. Fuhrman \& Azam 1980). In Stages 1 and 2, the organisms were supplied at a slower rate with a substrate that was partly exhausted. These stages were set to mimic the growth conditions of heterotrophic organisms below the autotrophic layer of the sea. While the levels and rates obtained are true for this particular system only, we believe the trends to be true indicators of general processes.

Several of the obtained results agree with earlier studies, especially results concerning processes induced by flagellate predation. Size-selective grazing (Andersson et al. 1986), excretion of DNA (Turk et al. 1992), and release of inorganic nutrients (Johannes 1965, Andersson et al. 1985, Goldman et al. 1985) by flagel- 
lates have been extensively discussed elsewhere. We have thus focused the discussion on results concerning organic carbon cycling and bacterial proliferation.

\section{DOC degradation}

A surprising finding was the increased utilization of DOC in the presence of flagellates. This could be attributed to either enhanced bacterial degradation or flagellate assimilation of DOC. Since flagellates mediate remineralization, increasing both the availability of inorganic nutrients and organic substrates, this could obviously enhance further bacterial degradation of DOC. The nutrient addition experiments, however, showed that adaitions of inorgañic nitutients could not stimulate bacterial growth (Table 5). Thus, with bacteria only, the remaining DOC was apparently nondegradable and the bacteria were unable to sequester more carbon. It has been suggested that co-metabolism could enhance bacterial degradation of refractory DOC, i.e. that additional substrates could support bacteria with energy to degrade refractory material (Brock et al. 1994). The possibility that the flagellates released such substrate and thus enabled the bacteria to break down additional DOC cannot be excluded based on our data. However, in a recent mesocosm experiment in which glucose was added to enhance degradation of non-degradable DOC (algal produced, stable isotope labelled), no further degradation of DOC could be demonstrated (Fry et al. 1996). Thus we feel justified in looking for alternative explanations.

Direct consumption of DOM by flagellates is known to occur but not in rates considered to be important for the transport of carbon in the microbial food web (Fenchel 1987). Flagellates are also able to ingest 'colloidal' DOM (Sherr 1988, Tranvik et al. 1993) as well as virus particles (González \& Suttle 1993). Under conditions similar to those in $B F_{1}$ and $\mathrm{BF}_{2}$, flagellates have been shown to ingest virus-like particles with an ingestion rate of 0.054 particles cell-1 $\mathrm{min}^{-1}$ (Gionzález \& Suttle 1993). Assuming a viral carbon content of $7 \times$ $10^{-18} \mathrm{~mol} \mathrm{C}$ (Bratbak et al. 1992), the loss of dissolved carbon due to flagellate grazing on viruses in our system would be about $9 \mathrm{pM} \mathrm{Ch}^{-1}$. If DOM uptake is associated with vacuole formation (pinocytosis), the maximum volume ingested by a flagellate is about $100 \%$ of the cell volume per hour (Fenchel 1987). Using the biovolumes and numbers of flagellates derived in this study, about $20 \mathrm{nl}$ water will be passed through the flagellate community per hour. With a DOC pool of $150 \mu \mathrm{M} \mathrm{C}$, a maximum of $3 \mathrm{pM} \mathrm{DOC} \mathrm{h}^{-1}$ is passed through the food vacuoles of the flagellates. Since the increased consumption of DOC in the presence of flagellates was 5 to $10 \mathrm{nMC} \mathrm{h}^{-1}$, virus ingestion or pinocytosis of DOC by flagellates could not explain the enhanced DOC degradation.

Relatively high assimilation rates can be accounted for, however, it the surface of the flagellates can serve as a collector of DOM. The encounter rates depend much on the structure of the DOM (Shimeta 1993). Stringy structures diffuse slowly but are efficiently encountered due to the high swimming velocities of flagellates. Smaller particles and molecules may be deflected along stream-lines as the flagellates swim past and are missed and not intercepted directly. However, encounter probability can nevertheless be high due to rapid diffusion towards the flagellate as it approaches, a process which depends on the diffusion rate of the matter to be encountered. It is illustrative to evaluate encounter rates for the 2 extreme situations of non-deflective interception and encounter by diffusion. Assuming a flagellate radius $(r)$ of $2 \mu \mathrm{m}$ and a swimming velocity $\left(v\right.$ ) of $100 \mu \mathrm{m} \mathrm{s}^{-1}$, a flagellate clears $\pi r^{2} v=4.5 \mathrm{nl} \mathrm{h}^{-1}$ by simply moving through the water. Assuming a diffusion coefficient $(D)$ of $10^{-6} \mathrm{~cm}^{2} \mathrm{~s}^{-1}$ (molecular weight on the order of $1000 \mathrm{Da}$ ), it clears $4 \pi r D=9 \mathrm{nl} \mathrm{h}^{-1}$ by diffusion alone irrespective of swimming speed. At $4 \times 10^{5}$ flagellates $\mathrm{l}^{-1}$ and $150 \mu \mathrm{MC}$, both potential encounter rates are high (on the order of $500 \mathrm{nM} \mathrm{C} \mathrm{h}^{-1}$ ) in relation to the observed reduction in $\mathrm{DOC}$ in the presence of flagellates (on the order of 5 to $10 \mathrm{nM} \mathrm{C} \mathrm{h}^{-1}$ )

If this scenario can be considered as a possible DOM pathway, a secondary question is then why flagellates are able to degrade DOM that was not accessible for the bacteria. Non-degradable DOM consists of molecules that most likely have been formed through abiotic processes (Azam et al. 1993, Keil \& Kirchman 1994). If these molecules cannot be recognized and cleaved by bacterial enzymes, they should not be accessible to flagellate enzymes either. However, it can be speculated that due to low pH and hydrolyzis processes in the food vacuoles DOM may be chemically 'pre-processed' into degradable products by the flagellate and either taken up directly by the flagellates or released and taken up by bacteria. While this question cannot be fully resolved based on the present data, we conclude that the presence of flagellates induced enhanced DOM degradation.

\section{Particulate organic matter}

The high concentration of POC found in the system indicated that detrital carbon (not seen with fluorescent dyes in the microscope) was produced. The detrital POC produced in the experiment made up maximally $3 \%$ of the total DOC pool. Bacterial lysis may have caused production of 'invisible' particles, or bac- 
teria may have produced material whose size or adsorptive tendencies ('stickiness') made them filterable. Biotic production of $\mathrm{POC}$ is likely related to the release of exopolymer material by bacteria and formation of TEP particles (transparent exopolymers) as observed in seawater (Alldredge et al. 1993, Heissenberger \& Herndl 1994). In the presence of flagellates the detrital POC increased additionally, and this may be attributed to egestion of small particles from the flagellate food vacuoles (Koike et al. 1990). An artefact that may have caused abiotic particle formation was the air stream which created bubbles in the culture vessels (see 'Material and methods'). Bubbling of seawater is known to create particles, both small and large in size (Johnson et al. 1986). Whether the detrital organic carbon was produced by biological or abiotic activity cannot be determined from the present data. However, the additional formation of detritus in the presence of flagellates suggest biological activity.

\section{Wall growth and medium stability}

When seawater is contained, the walls of the container are never free of growing organisms. To evaluate the importance of possible wall growth in the experimental system 2 different approaches were used. Midway through the experiment the culture vessels were changed by aseptic transfer of the cultures to new acid washed bottles (Ammerman et al. 1984). The old empty bottles were rinsed and shaken several times with particle-free sterile seawater with $0.1 \%$ Triton X-100 and the numbers of released bacteria were counted. Secondly, at the end of the experiment the accumulation of $\mathrm{N}$ and $\mathrm{P}$ on the walls was determined by rinsing the empty bottles twice with $50 \mathrm{ml} 1 \mathrm{M} \mathrm{HCl}$ and subsequently measuring the total $N$ and $P$. The bacterial counts midway through the experiment showed that wall-growing bacteria made up a maximum of $18 \%$ of total bacteria in $\mathrm{B}_{0}$, decreasing to $4 \%$ in $\mathrm{B}_{2}$. This amounts to $<1 \%$ of the total production of bacteria in the vessels up to the time when the bottles were changed (after $5.5 \mathrm{mo}$ ). The total $\mathrm{N}$ and $\mathrm{P}$ that was recovered from the walls at the end of the experiment made up 1 to $5 \%$ of total $\mathrm{N}$ and $\mathrm{P}$ in the bulk. If back-calculated to bacterial equivalents, a maximum of $17 \%$ of total bacteria would be present on the wall of the smallest bottle $\left(B_{0}\right)$ and $3 \%$ in $B_{2}$. The difference in amount of colonization between the bottles can in part be explained by the decreasing area:volume ratio (from 6 to 2 ) in bottles with increasing residence time. Together with the fact that none of the biological or chemical variables (except nitrate) showed any significant trend with time, we concluded that initial colonization of the walls rapidly reached equilibrium with the bacterial community of the bulk phase, and we have not made any corrections for wall growth. Another concern was aging of the medium seawater. Transformation of fresh material to non-degradabie DOC has been shown to occur as the result of unspecific chemical reactions, such as glycosylation and racemic transformation. The factors controlling these processes are poorly known, but facilitated under light conditions. Being initially rapid and slowing with time, the rates appear to be high enough to significantly influence the DOC dynamics in the surface water (Keil \& Kirchman 1994). In our system we did not find evidence of transformation of fresh to non-degradable DOC during the 11 mo that the system was operated. If the medium were subjected to continuous 'humification', a decrease in bacterial abundance during the time course of the experiment would have been observed. Hence, we believe that transformation of utilizable to non-degradable DOC may have been prevented due to the cold and dark storage of the experimental water or that possible reactions occurred before the experiment was started (i.e. between sampling of the medium and start of experiment).

\section{Bacterial growth at long residence time}

Although the experimental system resembles a multi-stage chemostat, it is important to recognize that in contrast to a true chemostat, this system was controlled by several mortality factors. The only loss term in a true chemostat is the outflow, while in this experimental system flagellate predation, virus lysis and autolysis must also be accounted for. In a similar flowthrough system Tempest et al. (1967) showed that the viability of Aeromonas aerogenes decreased to $35 \%$ at a dilution rate of $0.004 \mathrm{~h}^{-1}$. This in turn gave the fraction of living bacteria a specific growth rate of $0.01 \mathrm{~h}^{-1}$, i.e. substantially higher than the dilution rate (Tempest et al. 1967). Our results indicate several internal loops supporting rapid growth of a small but active bacterial community. In Fig. 7 a conceptual model is depicted to illustrate the carbon flows. Bacterial biomass production is only attributed to uninfected bacteria (or bacteria with lysogenic phages incorporated into the chromosome). Lysis of bacteria results in release of DOM-creating options for 'cryptic' growth in a closed system. POM are produced either as bacterial envelopes still visible in the microscope or as partly disintegrated membranes not visible in the microscope. Via enzymatic degradation (dashed lines on Fig. 7), the POM is finally returned to the DOM pool and subsequently reutilized by the bacteria. This internal circulation of organic carbon and the presence of flagellates makes it difficult to quantify production/ 


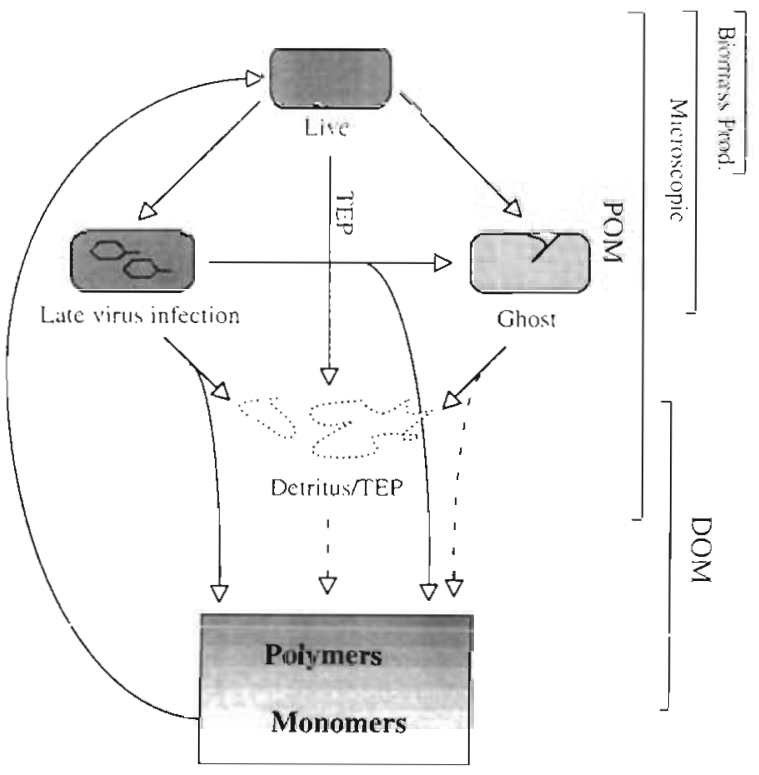

Fig. 7. Conceptual model of bacterial organic carbon turnover

degradation rates from the obtained steady-state values. In $B_{1}$ the increase in total numbers of bacteria was low compared with the inflow and in $\mathrm{B}_{2}$ bacterial counts decreased. This could be interpreted as bacteria barely surviving on maintenance energy or dying (Table 6). However, at the same time uptake of TTI and estimates of growth from the yield experiments indicated a substantial production of cells in all 5 vessels. To evaluate the importance of internal circulation of material a dynamic model based on common concepts of microbial processing of organic carbon is presented in an accompanying paper (Blackburn et al. 1996 in this issue).

Acknowledgements. Skilful technical assistance was provided by Asa Rudehäll, Susanne Berggren, Carl Stangenberg, Johan Nordbäck and Kerstin Jacobsson. Johan Wikner is acknowledged for kindly providing the data on viral numbers. This work was supported by grants from the Swedish National Science Council and Commission of the European Communities, MAST II grant MAS 2-CT93-0063 'Medipelagos'

\section{LITERATURE CITED}

Alldredge AL, Passow U, Logan BE (1993) The abundance and significance of a class of large, transparent organic particles in the ocean. Deep Sea Res 40:1131-1140

Ammerman JW, Fuhrman JA, Hagström A., Azam F (1984) Bacterioplankton growth in seawater. [. Growth kinetics and cellular characteristics in seawater cultures. Mar Ecol Prog Ser 18:31-39

Amon RMW, Benner R (1994) Rapid cycling of high-molecular-weight dissolved organic matter in the ocean. Nature $369: 549-552$
Andersson A, Larsson U, Hagström $\AA$ (1986) Size selective grazing by a microflagellate on pelagic bacteria. Mar Ecol Prog Ser 33:51-57

Andersson A, Lee C, Azam F, Hagstrom A (1985) Release of amino acids and inorganic nutrients by heterotrophic marine microflagellates. Mar Ecol Prog Ser 23: 99-106

Azam F, Smith DC, Steward GF, Hagström $\AA$ (1993) Bacteriaorganic-matter coupling and its significance for oceanic carbon cycling. Microb Ecol 28:167-179

Baretta-Bekker JG, Riemann B, Baretta JW, Rasmussen EK (1994) Testing the microbial loop concept by comparing mesocosm data with results from a dynamical simulation model. Mar Ecol Prog Ser 106:187-198

Blackburn N, Zweifel UL, Hagström § (1996) Cycling of marine dissolved organic matter. II. A model analysis. Aquat Microb Ecol 11:79-90

Børsheim KY, Bratbak G (1987) Cell volume to cell carbon conversion factors for a bacterivorous Monas sp. enriched from seawater. Mar Ecol Prog Ser $3 \bar{b}: i \bar{f} i-i \overline{7} j$

Bratbak G, Heldal M, Thingstad TF, Riemann B, Haslund $\mathrm{OH}$ (1992) Incorporation of viruses into the budget of microbial C-transfer. A first approach. Mar Ecol Prog Ser 83: $273-280$

Brock TD, Madigan MT, Martinko JM, Parker J (1994). Biology of microorganisms. Prentice Hall, New Jersey

Cochlan WP, Wikner J, Steward GF, Smith DC, Azam F (1993) Spatial distribution of viruses, bacteria and chlorophyll a in neritic, oceanic and estuarine environments. Mar Ecol Prog Ser 92:77-87

Coffin RB, Connolly JP, Harris PG (1993) Availability of dissolved organic carbon to bacterioplankton examined by oxygen utilization. Mar Ecol Prog Ser 101:9-22

Deflaun M, Paul JH, Davis D (1986) Simplified method for dissolved DNA determination in aquatic enviroments. Appl Environ Microbiol 52:654-659

Ducklow HW (1983) Production and fate of bateria in the oceans BioScience 33:494-501

Fenchel T (1987) The biology of free-living phagotrophic protists. Science Tech, Inc., Madison

Fry B, Hopkinson CSJ, Nolin A, Norrman B, Zwejfel UL (1996) Long-term decomposition of doc from an experimental diatom bloom. Limnol Oceanogr (in press)

Fuhrman JA (1992) Bacterioplankton roles in cycling of organic matter: the microbial food web. In: Falkowski PG, Woodhead AD (eds) Primary productivity and biogeochemical cycles in the sea. Plenum Press, New York, p 361-383

Fuhrman J, Azam F (1980) Bacterioplankton secondary production estimates for coastal waters of British Columbia, Antarctica, and California. Appl Environ Microbiol 39 $1085-1095$

Fuhrman J, Azam F (1982) Thymidine incorporation as a measure of heterotrophic bacterioplankton production in marine surface waters: evaluation and field results. Mar Biol 66:109-120

Goldman JC, Caron DA, Andersen OK, Dennett MR (1985) Nutrient cycling in a microflagellate food chain: I. Nitrogen dynamics. Mar Ecol Prog Ser 24:231-242

González JM, Suttle CA (1993) Grazing by marine nanoflagellates on viruses and virus-sized particles: ingestion and digestion. Mar Ecol Prog Ser 94:1-10

Grasshof K, Ehrhardt M, Kremling K (1983) Methods of seawater analysis. Chemie Verlag $\mathrm{GmbH}$, Weinheim

Haas LW (1982) Improved epifluorescence microscopy for observing planktonic micro-organisms. Ann Inst Océanogr $58: 261-266$ 
Hagström $\AA$, Ammerman JW. Henrichs S, Azam F (1984) Bacterioplankton growth in seawater: 1l. Organic matter utilization during steady-state growth in seawater cultures. Mar Ecol Prog Ser 18:41-48

Herssenberger A. Herndl GJ (1994) Formation of high molecular weight material by free-living marme bacteria. Mar Ecol Prog Ser 111:129-135

Hobbie JE, Daley RJ, Jasper S (1977) Use of Nuclepore filters for counting bacteria by fluorescence microscopy. Appl Environ Microbiol 33:1225-1228

Johannes RE (1965) Influence of marine protozoa on nutrient regeneration. Limnol Oceanogr 10:434-442

Johnson BD, Zhou X, Wangersky PJ (1986) Surface coagulation in seawater. Neth J Sea Res 20:201-210

Keil RG, Kirchman DL (1993) Dissolved combined amino acids: chemical from and utilization by marine bacteria. Limnol Oceanogr 38:1256-1270

Keil RG, Kirchman DL (1994) Abiotic tranformation of labile protein to refractory protein in seawater Mar Chem 45: $187-196$

Koike 1, Shigemitsu H, Kazuki T, Kogure K (1990) Role of submicrometer particles in the ocean. Nature 345:242-244

Middelboe M, Sandergaard M (1993) Bacterioplankton growth yield: seasonal variations and coupling to substrate lability and b-glucosidase activity. Appl Environ Microbiol 59: 3916-3921

Pomerantz SC, McCloskey JA (1990) Analysis of RNA hydralyzates by liquid chromatography-mass spectrometry. Meth Enzymol 193:796-824

Porter KG, Feig YS (1980) The use of DAPI for identifying and counting aquatic microflora. Limnol Oceanogr 25:943-948

Rosenberg R, Dahl E, Edler L, Fyrberg L, Granéli E, Granéli W, Hagström $\AA$, Lindahl $O$, Matos MO, Pettersson $K$, Sahlsten E, Tiselius P, Turk V, Wikner J (1990) Pelagic nutrient and energy transfer during spring in open and coastal Skagerrak. Mar Ecol Prog Ser 61:215-231

Responsible Subject Editor: P. M. Glibert, Cambridge, Maryland, USA
Sherr EB (1988) Direct use of high molecular weight polysaccharide by heterotrophic flagellates. Nature 335:348-351

Shimeta J (1993) Diffusional encounter of submicrometer particles and small cells by suspension feeders. Limnol Oceanogr 38:456-465

Sieburth JM, Johnson KM, Burney CM, Lavoie DM (1977) Estmation of in situ rates of heterotrophy using diurnal changes in dissolved organic matter and growth rates of picoplankton in diffusion culture. Helgol Wiss Meeresunters 30:565-574

Simon M. Azam F (1989) Protein content and protein synthesis rates of planktonic marine bacteria. Mar Ecol Prog Ser 51:201-213

Sundh I (1992) Biochemical composition of dissolved organic carbon derived from phytoplankton and used by heterotrophic bacteria. Appl Environ Microbiol 58:2938-2947

Taylor AH, Joint I (1990) A steady-state analysis of the 'microbial loop' in stratified systems. Mar Ecol Prog Ser 59:1-17

Tempest DW, Herbert D, Phipps PJ (1967) Studies on the growth of Aerobacter aerogenes at low dilution rates in a chemostat. Microbial Physiology and Continuous Culture, Proc 3rd Int Symp. Her Majesty's Stationery Office, London, p 240-253

Tranvik LJ, Sherr EB, Sherr BF (1993) Uptake and utilization of 'colloidal DOM' by heterotrophic flagellates in seawater. Mar Ecol Prog Ser 92:301-309

Turk. V, Rhenstam AS, Lundberg E, Hagström \& (1992) Release of bacterial DNA by marine nanoflagellates, an intermediate step in phosphorus regeneration. Appl Environ Microbiol 58:3744-3750

Zweifel UL, Hagström $\AA$ (1995) Total counts of marine bacteria include a large fraction of non-DNA containing ghosts. Appl Environ Microbiol 61:2180-2185

Zweifel U, Norman B, Hagström Å (1993) Consumption of dissolved organic carbon by marine bacteria and demand for inorganic nutrients. Mar Ecol Prog Ser 101:23-32

Manuscript first received: July 12, 1995

Revised version accepted: April 8, 1996 